\title{
Techno-Economic Analysis of Power Production by Using Waste Biomass Gasification
}

\author{
Sahar Safarian*, Runar Unnthorsson, Christiaan Richter \\ Faculty of Industrial Engineering, Mechanical Engineering and Computer Science, University of Iceland, \\ Reykjavik, Iceland \\ Email: *sas79@hi.is
}

How to cite this paper: Safarian, S., Unnthorsson, R. and Richter, C. (2020) Techno-Economic Analysis of Power Production by Using Waste Biomass Gasification. Journal of Power and Energy Engineering, 8, 1-8.

https://doi.org/10.4236/jpee.2020.86001

Received: May 13, 2020

Accepted: June 8, 2020

Published: June 11, 2020

Copyright $\odot 2020$ by author(s) and Scientific Research Publishing Inc. This work is licensed under the Creative Commons Attribution International License (CC BY 4.0).

http://creativecommons.org/licenses/by/4.0/

\begin{abstract}
Energy recovery from waste biomass can have significant impacts on the most pressing development challenges of rural poverty and environmental damages. In this paper, a techno-economic analysis is carried out for electricity generation by using timber and wood waste $(\mathrm{T} \& \mathrm{WW})$ gasification in Iceland. Different expenses were considered, like capital, installation, engineering, operation and maintenance costs and the interest rate of the investment. Regarding to revenues, they come from of the electricity sale and the fee paid by the Icelandic municipalities for waste collection and disposal. The economic feasibility was conducted based on the economic indicators of net present value (NPV) and discounted payback period (DPP), bringing together three different subgroups based on gasifier capacities, subgroup a: $50 \mathrm{~kW}$, subgroup b: $100 \mathrm{~kW}$ and subgroup c: $200 \mathrm{~kW}$. The results show that total cost increases as the implemented power is increased. This indicator varies from $1228.6 \mathrm{k} €$ for subgroups a to $1334.7 \mathrm{k} €$ for subgroups $\mathrm{b}$ and $1479.5 \mathrm{k} €$ for subgroups $\mathrm{c}$. It is worth mentioning that NPV is positive for three subgroups and it grows as gasifier scale is extended. NPV is about $122 \mathrm{k} €(111,020 \$)$, $1824 \mathrm{k} €(1,659,840 \$)$ and $4392 \mathrm{k} €(3,996,720 \$)$ for subgroups a, b and $\mathrm{c}$, respectively. Moreover, DPP has an inversely proportional to the installed capacity. It is around 5.5 years (subgroups a), 9.5 months (subgroups b) and 6 months (subgroups $\mathrm{c}$ ). The obtained results confirm that using small scale waste biomass gasification integrated with power generation could be techno-economically feasible for remote area in Iceland.
\end{abstract}

\section{Keywords}

Waste Biomass Gasification, Techno-Economic Analysis, Power Production, Waste to Energy 


\section{Introduction}

The rapid development of global economy, increasing population and living standards has been posing great pressure on energy resources and the environment. There is an urgency to use local renewable energies to promote local development and also reduce carbon emission. Waste biomass is an abundant and renewable energy that creates low net $\mathrm{CO}_{2}$ emission. It is also the only suitable and primary energy resource that can provide transportation fuels [1] [2] [3]. Biomass gasification is an attractive option that is getting huge attention for conversion of different feedstocks to energy. In the gasification, a partial oxidation at elevated temperature $\left(600^{\circ} \mathrm{C}-1700^{\circ} \mathrm{C}\right)$ is happened that converts organic components to a Synthesis Gas (syngas), consisting mainly of $\mathrm{CO}, \mathrm{H}_{2}, \mathrm{CH}_{4}$, tars, inorganic impurities and particulates [4] [5].

Beneficially, waste biomass gasification can be applied for small/medium scales that lead to dramatic reduction of some pollutants emission as furans, dioxins, and NOx and the possibility of the utilization of the syngas in high efficiency thermal devices like internal combustion engine and gas turbines [6]. Hence, waste biomass gasification can be installed as a reliable energy supply technology for places which are far from the central energy networks and require district heat and power systems [7] [8] [9].

In this paper, we will explore the potential of timber and wood waste ( $\mathrm{T} \&$ WW) gasification for energy production in small communities in Iceland, (T \& WW is the most existing biomass feedstock in this country). In this way, a techno-economic analysis of T \& WW gasification facilities integrated with electricity generation unit will be directed for three subgroups with different gasifier installed power, 1): $50 \mathrm{~kW}, 2): 100 \mathrm{~kW}$ and 3): $200 \mathrm{~kW}$ to propose a sustainable waste to power system adapted with conditions in Iceland.

\section{Material and Methods}

\subsection{Process Description}

Figure 1 shows the studied system in this paper. T \& WW is the significant resource entering to the system, liquid fuel and electricity are also the accessory inputs. The proximate and elemental analyses of $\mathrm{T} \& \mathrm{WW}$ are shown in Table 1.

$\mathrm{T} \& \mathrm{WW}$ is transferred from the waste fields to pre-processing part that is next to gasification and electricity generation unit. Diesel fuel is used in trucks

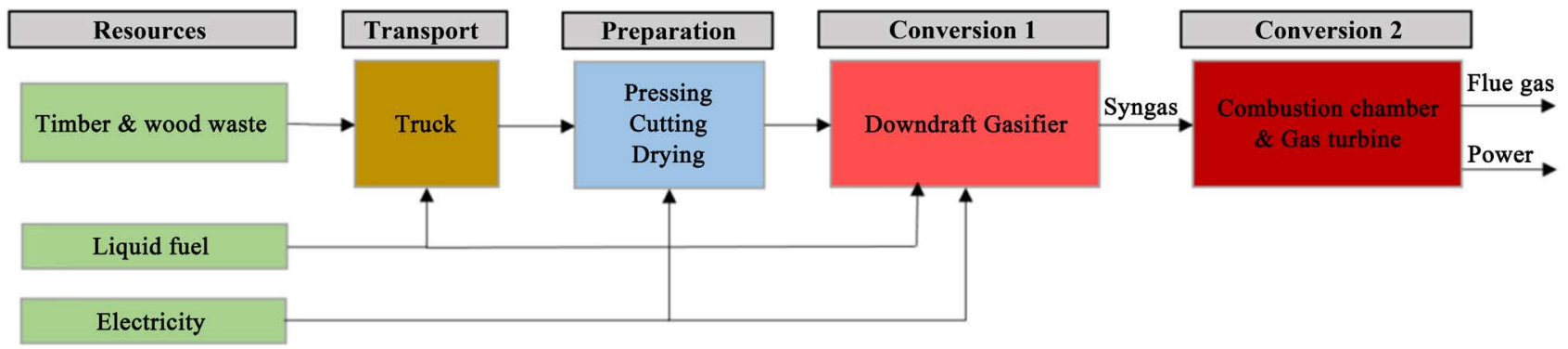

Figure 1. System boundaries, technologies, energy and material streams. 
Table 1. Ultimate and proximate analysis of T \& WW [10].

\begin{tabular}{cc}
\hline Parameters & Value (\%) \\
\hline Proximate analysis (wt\%) & 5.01 \\
Moisture & 93.06 \\
Volatile matter (VM) & 6.38 \\
Fixed carbon (FC) & 0.56 \\
Ash & \\
Ultimate analysis (wt\%-dry basis) & 56.8 \\
C & 7.28 \\
H & 0.18 \\
N & 0.82 \\
Cl & 0.07 \\
S & 34.29 \\
O & \\
\hline
\end{tabular}

for transportation and electricity is applied for driving force and heat generation over the process. The electricity production in Iceland is derived from geothermal and hydropower that makes Iceland's main source of clean energy. The gasification process consists of drying, pyrolysis, combustion and gasification [11]. In this work the down draft reactors are considered that operate at atmospheric pressure, to gasify $\mathrm{T} \& \mathrm{WW}$ and air is used as the gasification agent, resulting in $\mathrm{CO}_{2}$ and $\mathrm{H}_{2} \mathrm{O}$, which subsequently undergo reduction upon contact with the char produced from pyrolysis. Reduction yields combustible gases as $\mathrm{H}_{2}, \mathrm{CO}$, and $\mathrm{CH}_{4}$ through a series of reactions [5] [12]. Then the produced syngas enters a combustion chamber followed by a gas turbine. The combination of these two modules represents the behavior of a combustion engine where the reaction with air occurs [13] [14]. The inputs values and key assumptions used in this work are based on our waste biomass gasification simulation model developed by ASPEN Plus [8] and the main values of the downdraft gasifiers characteristics, operational parameters and the flue gas composition are relied on our previous work [15].

\subsection{Techno-Economic Assessment}

In the economic assessment, all prices are expressed in $\mathrm{K} €$ (kilo-euro) and the interest rate is $8 \%$. A computer program has been developed to investigate economically for three subgroups of $50 \mathrm{~kW}, 100 \mathrm{~kW}$ and $200 \mathrm{~kW}$ of gasifier installed power. The model is able to evaluate the cash flow analysis, total cost, Net Present Value (NPV) and Discounted Payback Period (DPP). A project is an economically attractive while it has the lowest DPP and the NPV higher than zero. NPV is calculated based on Equation (1) [16]:

$$
N P V=\sum_{n=1}^{t} \frac{C F_{n}}{(1+r)^{n}}-C_{c}
$$

where $C F_{n}$ is the annual cash flow, being the difference between Revenues $(R)$ 
and Expenditures $(E)$, Operation and Maintenance Costs $\left(C_{O \& M}\right), r$ is the discount rate, $C_{c}$ is the total capital costs of investment and $t$ is the lifetime of the investment (15 years). DPP is calculated according to Equation (2):

$$
D P P=\frac{L N\left(\frac{1}{1-\frac{C_{c} \times r}{C F}}\right)}{L N(1+r)}
$$

The periodic cash flow, with all the revenues and expenditures, is calculated by considering the incomes from the generated electricity, and the credits for the Waste Treatment Bill (WTB) [6]. The expenditures also include the $C_{c}$ and $C_{O \& M}$ $C_{c}$ is divided into three categories: hardware price $\left(C_{g}\right)$, installation cost $(25 \%$ of $C_{g}$ ) and engineering costs, the engineering costs includes engineering and design $\left(13 \%\right.$ of $\left.C_{g}\right)$, purchasing \& construction $\left(14 \%\right.$ of $\left.C_{g}\right)$, fuel handling/preparation ( $9 \%$ of $C_{g}$ ) and electrical/balance of plant (6\% of $C_{g}$ ) [17] [18]. $C_{g}$ is the price of gasifier system overally on the basis of various capacities. In this work, we extracted gasifier prices from various companies [19] [20]. $C_{g}$ was considered 73.6 $\mathrm{k} €, 105.5 \mathrm{k} €$ and $147.5 \mathrm{k} €$ for $50 \mathrm{~kW}, 100 \mathrm{~kW}$ and $200 \mathrm{~kW}$, respectively.

The whole yearly $C_{O \& M}$ can be determined by the sum of the costs for the maintenance cost $\left(2 \%\right.$ of $\left.C_{c}\right)$, insurance and tax $\left(2 \%\right.$ of $\left.C_{c}\right)$, waste disposal $(15 \%$ of $C_{c}$ ), electricity cost, liquid fuel cost and personnel cost. Electricity costs are calculated based on electricity consumers and liquid fuel costs are estimated for fuel consumers with $7000 \mathrm{hr} /$ year of plant availability [17] [18]. The unitary cost of electrical and fuel energies supplied in Iceland are equal to $0.03 \$ / \mathrm{kWh}$ and $1.08 \$ /$ lit $(0.91 € / \$$ as conversion rate) [3]. Personnel cost includes annual labour, cost. A total of two employees were assumed for plant operation management ( 1 person/shift and 2 shifts/day), with a yearly cost of $60,000 € /$ year per person in Iceland.

In relation to revenues, the selling price of electricity to normal households and small businesses in Iceland is about 124.69 \$/MWh [21]. Hence, the sale price of the generated electricity based on waste gasification was considered at 109.89 \$/MWh (100 €/MWh) in our work. Moreover, The Icelandic municipalities pay a fee (WTB) by weight, to the private companies, for the collection and disposal the MSW in sanitary landfills. The WTB for collection and disposal of the MSW varies from $90-170 € /$ ton through over Iceland. In this work, a mean value of $130 € /$ ton is used.

\section{Results}

Figure 2 shows the relation between the installed power and the amount of $\mathrm{T} \&$ WW that is fed to the system for treatment and power production. Clearly, as the installed power grows, input biomass also increases. The requested waste biomass varies from $132.1 \mathrm{~kg} / \mathrm{hr}$ for the first subgroup to $309.5 \mathrm{~kg} / \mathrm{hr}$ for the second one and $575.3 \mathrm{~kg} / \mathrm{hr}$ for the third subgroup. 
The total cost of the generation plant for each subgroup is shown in Figure 3. The total cost increases as the installed power grows, it is about $1228.6 \mathrm{k} €$ (Subgroup a), $1334.7 \mathrm{k} €$ (Subgroup b) and $1479.5 \mathrm{k} €$ (Subgroup c). In addition, Figure 4 depicts the percentage shares of hardware, installation, engineering and annual

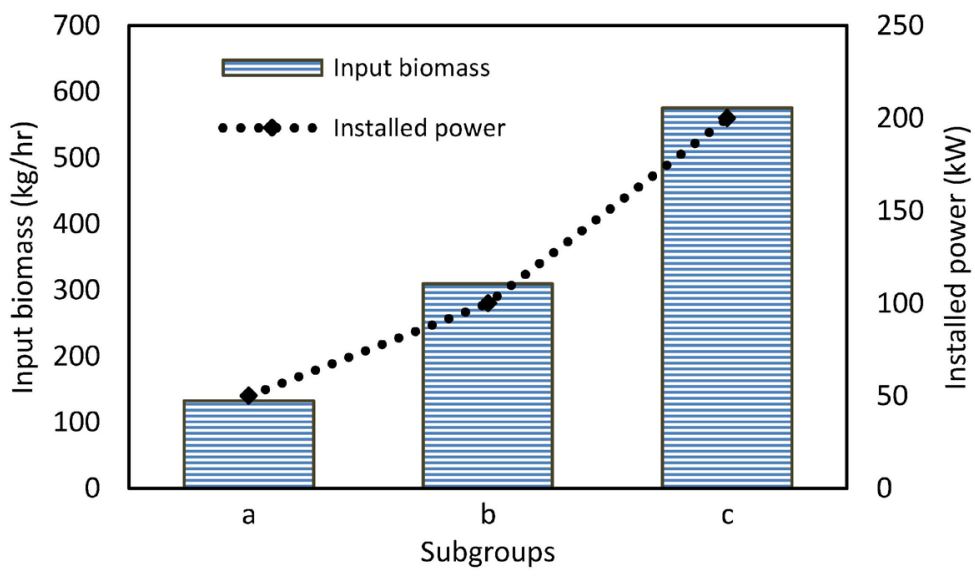

Figure 2. Input T \& WW and installed power for subgroups.

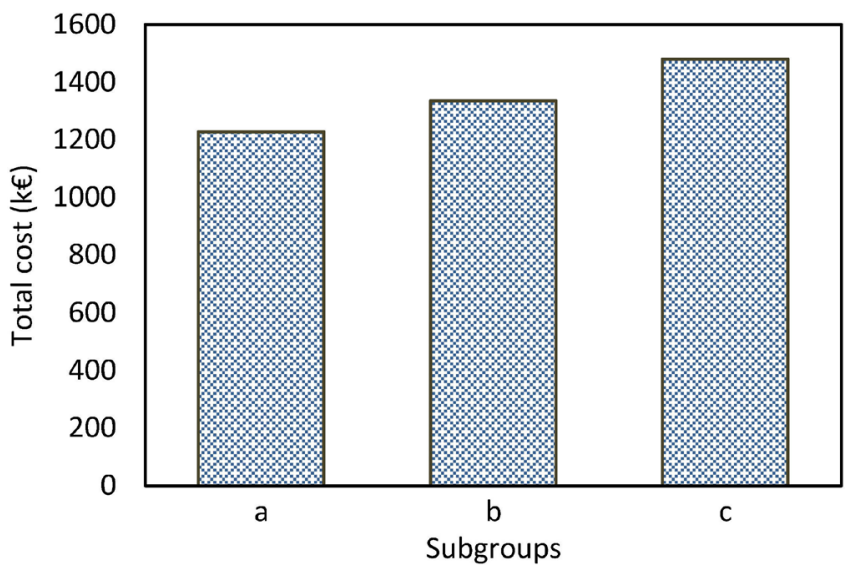

Figure 3. Total costs for different subgroups.

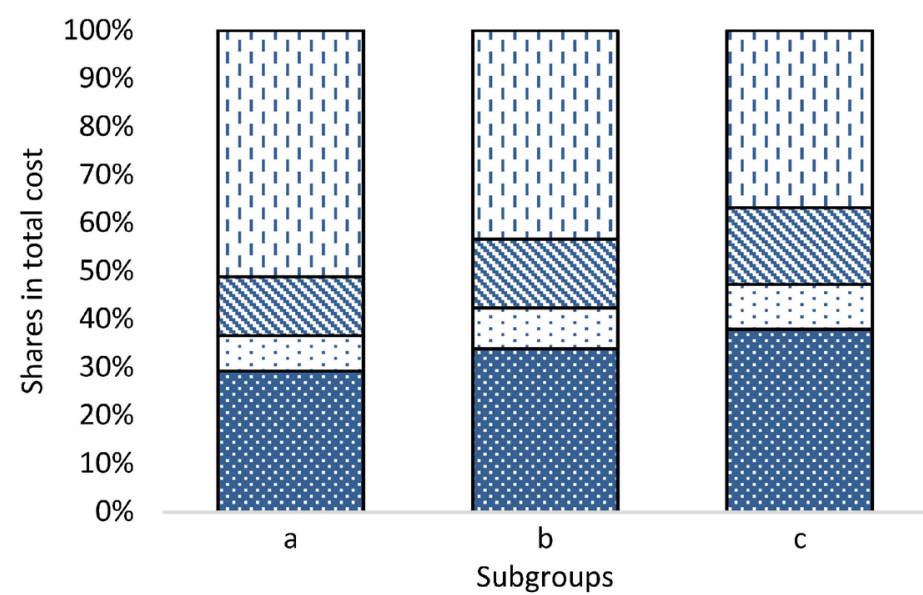

圆Hardware $\square$ Installation $\mathbf{0}$ Engineering $\square$ Yearly operating \& maintenance

Figure 4. Percentage shares of total cost. 


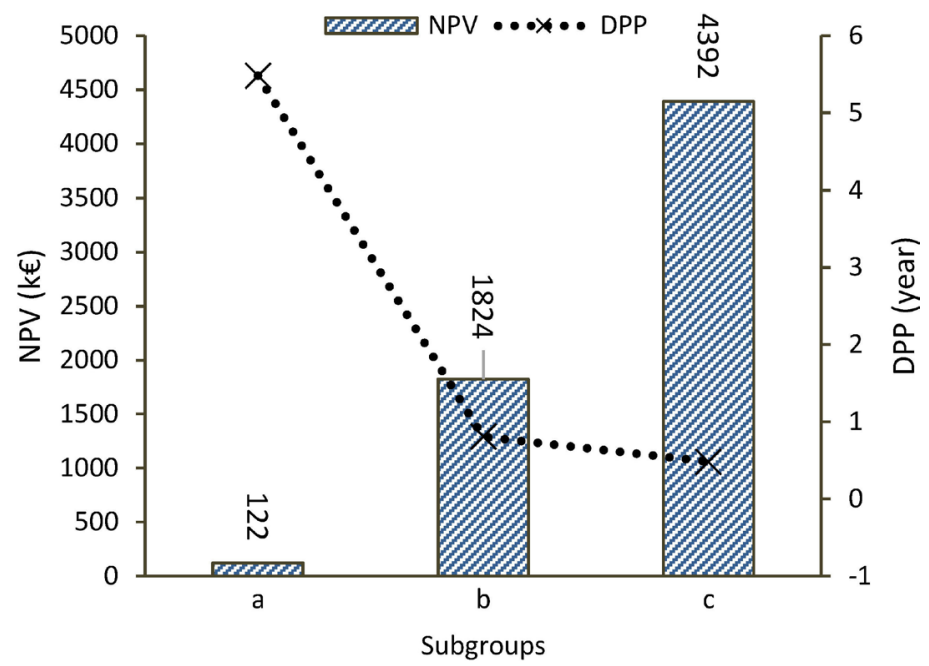

Figure 5. NPV and DPP for different subgroups.

$\mathrm{O} \& \mathrm{M}$ costs in total cost. The yearly O \& $\mathrm{M}$ costs occupies more than $55 \%$ of total cost for the first subgroup, it has also the dominant statue among different kinds of costs for subgroups b (43\%). However, the highest share is related to gasification system price for subgroups $c$.

The economic assessments, based on the indexes of NPV and DPP for three subgroups, are shown in Figure 5. It is worth mentioning that NPV is positive for three subgroups and it grows as gasifier scale is extended. NPV is about 122 $\mathrm{k} €, 1824 \mathrm{k} €$ and $4392 \mathrm{k} €$ for subgroups a, b and c, respectively. Moreover, DPP shows the gasification plant in this context is very feasible for Iceland. It has an inversely proportional to the installed capacity. It is around 5.5 years (subgroups a), 9.5 months (subgroups b) and 6 months (subgroups c).

\section{Conclusion}

In this work, techno-economic of power production plant that utilized syngas from a timber and wood waste gasification process in Iceland was investigated. The technical assessment focused mainly on input waste, and installed power. The economic assessment was conducted relied on the economic indicators of total cost, revenues, NPV and DPP, for three subgroups with different gasifier installed power, 1): $50 \mathrm{~kW}, 2$ ): $100 \mathrm{~kW}$ and 3): $200 \mathrm{~kW}$. The results show that total cost increases as the implemented power is increased. This indicator varies from 1228.6 $\mathrm{k} €$ for subgroups a to $1334.7 \mathrm{k} €$ for subgroups $\mathrm{b}$ and $1479.5 \mathrm{k} €$ for subgroups $\mathrm{c}$. It should be emphasized that NPV is positive for three subgroups and it grows as gasifier scale is extended. The NPV in subgroup c, is averagely $58 \%$ and $97 \%$ higher than subgroups b and a, respectively. NPV is about $122 \mathrm{k} €, 1824 \mathrm{k} €$ and $4392 \mathrm{k} €$ for subgroups $\mathrm{a}, \mathrm{b}$ and $\mathrm{c}$, respectively. Moreover, DPP has an inversely proportional to the installed capacity. It is around 5.5 years (subgroups a), 9.5 months (subgroups b) and 6 months (subgroups c). Finally, the obtained results confirm that using small scale waste biomass gasification integrated with power generation could be techno-economically feasible for remote area in Iceland. 


\section{Acknowledgements}

This paper was a part of the project funded by Icelandic Research Fund (IRF), (in Icelandic: Rannsoknasjodur) and the grant number is 196458-051.

\section{Conflicts of Interest}

The authors declare no conflicts of interest regarding the publication of this paper.

\section{References}

[1] Safarian, S., Sattari, S. and Hamidzadeh, Z. (2018) Sustainability Assessment of Biodiesel Supply Chain from Various Biomasses and Conversion Technologies. BioPhysical Economics and Resource Quality, 3, 6. https://doi.org/10.1007/s41247-018-0039-2

[2] Safarian, S., et al. (2019) Prioritization of Bioethanol Production Systems from Agricultural and Waste Agricultural Biomass Using Multi-Criteria Decision Making. Biophysical Economics and Resource Quality, 4, 4. https://doi.org/10.1007/s41247-019-0052-0

[3] Safarian, S. and Unnthorsson, R. (2018) An Assessment of the Sustainability of Lignocellulosic Bioethanol Production from Wastes in Iceland. Energies, 11, 1493. https://doi.org/10.3390/en11061493

[4] Ofori-Boateng, C., Lee, K.T. and Mensah, M. (2013) The Prospects of Electricity Generation from Municipal Solid Waste (MSW) in Ghana: A Better Waste Management Option. Fuel Processing Technology, 110, 94-102. https://doi.org/10.1016/j.fuproc.2012.11.008

[5] Safarian, S., Unnpórsson, R. and Richter, C. (2019) A Review of Biomass Gasification Modelling. Renewable and Sustainable Energy Reviews, 110, 378-391. https://doi.org/10.1016/j.rser.2019.05.003

[6] Luz, F.C., et al. (2015) Techno-Economic Analysis of Municipal Solid Waste Gasification for Electricity Generation in Brazil. Energy Conversion and Management, 103, 321-337. https://doi.org/10.1016/j.enconman.2015.06.074

[7] Safarian, S., Richter, C. and Unnthorsson, R. (2019) Waste Biomass Gasification Simulation Using Aspen Plus: Performance Evaluation of Wood Chips, Sawdust and Mixed Paper Wastes. Journal of Power and Energy Engineering, 7, 12-30. https://doi.org/10.4236/jpee.2019.76002

[8] Safarian, S., Unnthorsson, R. and Richter, C. (2020) Performance Analysis and Environmental Assessment of Small-Scale Waste Biomass Gasification Integrated CHP in Iceland. Energy, 197, Article ID: 117268. https://doi.org/10.1016/j.energy.2020.117268

[9] Safarian, S., Unnthorsson, R. and Richter, C. (2020) Simulation of Small-Scale Waste Biomass Gasification Integrated Power Production: A Comparative Performance Analysis for Timber and Wood Waste. International Journal of Applied Power Engineering, 9, 147-152.

[10] Freeman, M., et al. Biomass Cofiring R\&D and Demonstration Results for Handling, Combustion, Heat Transfer, and Emissions Issues for Coal-Fired Boilers. https://www.researchgate.net/profile/Gary_Walbert/publication/228425742_Biomass_ Cofiring_RD_and_Demonstration_Results_for_Handling_Combustion_Heat_Transfer_an 
d_Emissions_Issues_for_Coal-Fired_Boilers/links/56f1395708aec63f4c9b4f40.pdf

[11] Safarianbana, S., Unnthorsson, R. and Richter, C. (2019) Development of a New Stoichiometric Equilibrium-Based Model for Wood Chips and Mixed Paper Wastes Gasification by ASPEN plus. ASME 2019 International Mechanical Engineering Congress and Exposition, Salt Lake City, 11-14 November 2019, V006T06A002. https://doi.org/10.1115/IMECE2019-10586

[12] Samadi, S.H., Ghobadian, B. and Nosrati, M. (2019) Prediction and Estimation of Biomass Energy from Agricultural Residues Using Air Gasification Technology in Iran. Renewable Energy, 149, 1077-1091. https://doi.org/10.1016/j.renene.2019.10.109

[13] Safarian, S. and Bararzadeh, M. (2012) Exergy Analysis of High-Performance Cycles for Gas Turbine with Air-Bottoming. Journal of Mechanical Engineering Research, $5,38-49$.

[14] Safarian, S., Saboohi, Y. and Kateb, M. (2013) Evaluation of Energy Recovery and Potential of Hydrogen Production in Iranian Natural Gas Transmission Network. Energy Policy, 61, 65-77. https://doi.org/10.1016/j.enpol.2013.05.002

[15] Safarian, S., Unnthorsson, R. and Richter, C. (2020) Techno-Economic and Environmental Assessment of Power Supply Chain by Using Waste Biomass Gasification in Iceland. BioPhysical Economics and Sustainability, 5, 7.

[16] Safarian, S., Khodaparast, P. and Kateb, M. (2014) Modeling and Technical-Economic Optimization of Electricity Supply Network by Three Photovoltaic Systems. Journal of Solar Energy Engineering, 136, Article ID: 024501. https://doi.org/10.1115/1.4025120

[17] Sara, H.R., et al. (2016) Techno-Economic Analysis of Hydrogen Production Using Biomass Gasification-A Small Scale Power Plant Study. Energy Procedia, 101, 806-813. https://doi.org/10.1016/j.egypro.2016.11.102

[18] Porcu, A., et al. (2019) Techno-Economic Analysis of a Small-Scale Biomass-to-Energy BFB Gasification-Based System. Energies, 12, 494. https://doi.org/10.3390/en12030494

[19] Chongqing Fengyu Electric Co. http://feng-yu.com

[20] Qingdao Kexin New Energy Technology Co. https://qd-kexin.en.alibaba.com

[21] Orkusetur. https://orkusetur.is/reiknivelar/raforka/raforkuverd 